\title{
Karakteristik Pembentukan Karakter di SMP Islam Terpadu Izzuddin Palembang
}

\author{
Robi Awaludin \\ SD Islam Cendikia Faiha Palembang \\ Email: robiawludin@gmail.com
}

\begin{abstract}
Abstrak: Penelitian ini bertujuan untuk mengungkapkan karakteristik pembentukan karakter yang diterapkan di SMP Islam Terpadu Izzuddin Palembang dengan menggunakan pendekatan kualitatif. Pengumpulan data dilakukan dengan teknik wawancara mendalam, pengamatan berpartisipasi, dan dokumentasi. Teknik analisis data meliputi reduksi data, penyajian data, dan penarikan kesimpulan. Pengecekan keabsahan temuan dilakukan dengan cara perpanjangan pengamatan, meningkatkan ketekunan, triangulasi, analisis kasus negatif, menggunakan bahan referensi, dan mengadakan member check. Informan penelitian adalah kepala sekolah, wakil kepala sekolah bagian kurikulum, wakil kepala sekolah bidang kesiswaan, guru kelas, siswa dan orang tua/wali. Temuan penelitian menunjukkan bahwa karakter siswa yang dikembangkan di SMP Islam Terpadu Izzuddin Palembang bersumber dari nilai- nilai yang meliputi: Nilai karakter dalam hubungannya dengan Keagamaan/Religiusitas, Nilai karakter dalam hubungannya dengan personality/diri sendiri, Nilai karakter dalam hubungannya dengan sosial/sesama dan lingkungan, dan Nilai nasionalis/kebangsaan. Pola pembentukan karakter siswa di SMP Islam Terpadu Izzuddin Palembang diselenggarakan dengan pendekatan terpadu yang bertumpu pada tiga pilar/komponen, yaitu Pengembangan program dan kebijakan sekolah, Program pembelajaran, Kemitraan dengan wali siswa. Penelitian ini menghasilkan kesimpulan yang berupa proposisi, apabila pendidikan karakter didasarkan pada visi dan misi yang jelas, rumusan karakter dasar yang detail, prinsip-prinsip yang kuat dan metode-metode yang tepat, maka akan berjalan secara efektif dan efisien, bahwa apabila pola pembentukan karakter di dasarkan pada pendekatan terpadu, dengan melibatkan peran dan tanggung jawab semua komponen pendidikan di sekolah dan peran sera orang tua di rumah, maka akan berjalan efektif dan efisien.
\end{abstract}

\section{Kata Kunci: Pembentukan Karakter, Peserta Didik}

\begin{abstract}
This study aims at finding out the characteristics of character formation applied at Integrated Islamic Middle School Izzuddin Palembang using a qualitative approach. Research data was collected by in-depth interview techniques, participatory observations, and documentation. Data analysis techniques included data reduction, data presentation, and conclusion drawing. Checking the validity of the findings was done by extending the observation, increasing persistence, triangulation, analyzing negative cases, using reference material, and holding a member check. The research informants were principals, deputy principals in the curriculum section, vice principals in student affairs, classroom teachers, students and parents/guardians. Research findings indicated that the students' character developed at Integrated Islamic Middle School Izzuddin Palembang coming from the values that included: character values related to religion/religiousity, character values related to personality/self, character values related to social and environment, and nationality values. The pattern of character building of students at Integrated Islamic Middle School Izzuddin Palembang is organized with an integrated approach that relies on three pillars/components, namely the development of school programs and policies, the Learning Programs, and Partnerships with student guardians. This study yields a conclusion in the form of a proposition, if character education is based on a clear vision and mission, detailed basic character formulation, strong principles and appropriate methods, it will run effectively and efficiently. If the character formation pattern is based on an integrated approach, involving the roles and responsibilities of all components of education in schools and the role of parents at home, it will be effective and efficient.
\end{abstract}


Keywords: Character Building, Students

\section{Pendahuluan}

Pendidikan karakter tengah menjadi topik perbincangan yang menarik. Entah di sekolah-sekolah, forum seminar, diskusi di kampus-kampus maupun di berbagai media elektronik maupun media cetak. Pendidikan karakter, saat ini dan mungkin beberapa tahun ke depan sedang "ngetrend" dan "booming" itu tidak lepas dari gemparnya sosialisasi yang dilakukan Kementrian Pendidikan dan Kebudayaan, sebagai upaya memperbaiki karakter generasi muda pada khususnya dan bangsa ini pada umumnya. Dampak globalisasi yang terjadi saat ini membawa masyarakat Indonesia melupakan pendidikan karakter bangsa. Padahal, pendidikan karakter merupakan suatu pondasi bangsa yang sangat penting dan perlu ditanamkan sejak dini kepada anak-anak (Muslich, 2013:1).

Sementara itu, dalam dunia pendidikan kasus bertindak curang (cheating) baik berupa tindakan mencontek, mencontoh pekerjaan teman atau mencontoh dari buku pelajaran seolah-olah merupakan kejadian sehari-hari. Bahkan dalam pelaksanaan ujian akhir sekolah di beberapa daerah ditengarai ada guru yang memberikan kunci jawaban kepada siswa, karena takut muridnya tidak lulus sehingga mencoreng nama sekolah. Seakan-akan dalam dunia pendidikan kejujuran telah menjadi barang yang langka, contoh hilangnya kejujuran di masyarakat Indonesia seperti maraknya fenomena korupsi dan kolusi sudah amat banyak. Keprihatinan ini telah menjadi keprihatinan nasional, presiden Republik Indonesia menyampaikan dalam pidatonya: "Pembangunan watak (character building) amat penting. Kita ingin membangun manusia Indonesia yang berakhlak, berbudi pekerti, dan berperilaku baik. Bangsa kita ingin pula memiliki peradaban yang unggul dan mulia. Peradaban yang demikian dapat dicapai apabila masyarakat kita juga merupakan masyarakat yang baik (good society). Keharuman nama jarang bisa dipulihkan, ketika karakter lenyap semuanya juga lenyap. Satusatunya mutiara kehidupan yang paling berharga sirna selamanya. (Muchlas S dan Hariyanto, 2011: 5-6).

Berkaitan dengan dirasakan semakin mendesaknya implementasi pendidikan karakter di Indonesia, Pusat Kurikulum Badan Penelitian dan Pengembangan Kementerian Pendidikan Nasional dalam publikasinya berjudul Pedoman Pelaksanaan Pendidikan Karakter menyatakan bahwa pendidikan karakter pada intinya bertujuan membentuk bangsa yang tangguh, kompetitif, berakhlak mulia, bermoral, bertoleran, bergotong royong, berjiwa patriotik, berkembang dinamis, berorientasi ilmu pengetahuan dan teknologi yang semuanya dijiwai oleh iman dan takwa kepada Tuhan yang Maha Esa berdasarkan Pancasila (Muchlas S dan Hariyanto, 2011: 9). 
Sementara itu, terkait objek penelitian yang akan dilakukan oleh peneliti yaitu pada SMP Islam Terpadu Izzuddin Palembang, hal ini dikarenakan sekolah tersebut termasuk salah-satu sekolah Islam unggulan di Kota Palembang dan merupakan sekolah berbasis agama Islam yang sangat kental pada bidang keagamaan dan menekankan akhlak mulia pada siswanya, terlihat dari perilaku dan cara mengamalkannya dalam kehidupan sehari-hari. Seperti kegiatan pagi masuk kelas pada pukul 07.20 sampai dengan 07.30 diisi dengan : a) membaca do'a setiap sepuluh menit pertama di pagi hari sebelum KBM dimulai. Hal ini merupakan penanaman akhlak sejak dini kepada siswa bahwa dalam berniat untuk mencari ilmu harus diawali dengan berdo'a terlebih dahulu, b) sholat dhuha berjama'ah di masid, c) menghafal Al-Qur'an dengan tujuan untuk memberikan pengontrolan terhadap bacaan dan hafalan siswa, dan untuk menanamkan cinta Qur'an, sebab Al-Qur'an itu akan memberikan syafa'at kepada orang yang mau membacanya.

Pembentukan karakter di SMP Islam Terpadu Izzuddin Palembang menjadi tujuan sekolah itu yaitu untuk membentuk peserta didik yang berkarakter yang mempunyai sifat religius, jujur, disiplin, mandiri, peduli lingkungan, peduli sosial, dan tanggung jawab. Tujuan tersebut terkandung di dalam Visi-misi SMP Islam Terpadu Izzuddin Palembang yaitu "Membangun tradisi lingkungan sekolah yang berakhlak Islami".

\section{Kajian Literatur}

\section{Hakikat Karakter}

Secara bahasa, kata karakter berasal dari bahasa Yunani yaitu "charassein", yang berarti barang atau alat untuk menggores, yang di kemudian hari dipahami sebagai stempel/cap. Jadi, watak itu stempel atau cap, sifat-sifat yang melekat pada seseorang. Watak sebagai sikap seseorang dapat dibentuk, artinya watak seseorang berubah, kendati watak mengandung unsur bawaan (potensi internal), yang setiap orang dapat berbeda. Namun, watak amat sangat dipengaruhi oleh faktor eksternal, yaitu keluarga, sekolah masyarakat, lingkungan pergaulan, dan lain-lain (Sutarjo, 2013: 77).

Sutarjo (2013: 78) dengan mengutip pendapat F.W. Foerster menyebutkan bahwa karakter adalah sesuatu yang mengualifikasi seorang pribadi. Karakter menjadi identitas, menjadi ciri, menjadi sifat yang tetap, yang mengatasi pengalaman kontingen yang selalu berubah. Jadi karakter adalah seperangkat nilai yang telah menjadi kebiasaan hidup sehingga menjadi sifat tetap dalam diri seseorang, misalnya kerja keras, pantang menyerah, jujur, sederhana, dan lainlain.

Menurut Zuchdi (2008: 11) karakter adalah seperangkat sifat yang selalu dikagumi sebagai tanda-tanda kebaikan, kebajikan, dan kematangan moral 
seseorang. Lebih lanjut dikatakan bahwa tujuan pendidikan karakter adalah mengajarkan nilai-nilai tradisional tertentu, nilai-nilai yang diterima secara luas sebagai landasan perilaku yang baik dan bertanggung jawab.

Arismantoro (2008: 27) dengan mengutip pendapat Alwisol, menyebutkan bahwa karakter diartikan sebagai gambaran tingkah laku yang menonjolkan nilai benar-salah, baik-buruk, baik secara eksplisit maupun implisit. Karakter berbeda dengan kepribadian, karena pengertian kepribadian dibebaskan dari nilai. Meskipun demikian, baik kepribadian (personality) maupun karakter terwujud tingkah laku yang ditunjukkan ke lingkungan sosial.

Dalam bukunya yang berjudul "Pendidikan Karakter; Strategi Mendidik Anak di Zaman Global, Doni Koesoema (2010: 90-91) menjelaskan bahwa karakter dapat dilihat dari dua hal, yaitu pertama, sebagai sekumpulan kondisi yang telah ada begitu saja, atau telah ada begitu saja, yang lebih kurang dipaksakan pada diri kita. Karakter yang demikian ini dianggap sebagai sesuatu yang telah ada dari sononya (given). Kedua, karakter juga bisa dipahami sebagai tingkat kekuatan bilamana seseorang individu mampu menguasai kondisi tersebut. Karakter yang demikian ini disebut sebagai proses yang dikehendaki (willed).

Menurut Lickona (2013: 81) karakter diartikan sifat alami seseorang dalam merespons situasi secara bermoral. Lickona menekankan tiga hal dalam mendidik karakter, yang dirumuskan dengan indah: knowing, loving, and acting the good.

Menurut Naim (2013: 55) karakter adalah serangkaian sikap (attitude), perilaku (behaviors), motivasi (motivations), dan keterampilan (skills). Karakter meliputi sikap seperti keinginan untuk melakukan hal yang terbaik, kapasitas intelektual, seperti sikap kritis dan alasan moral, perilaku seperti jujur dan bertanggung jawab, mempertahankan prinsip-prinsip moral dalam situasi penuh ketidakadilan, kecakapan interpersonal dan emosional yang memungkinkan seseorang berinteraksi secara efektif dalam berbagai keadaan, dan komitmen untuk berkonstribusi dengan komunitas dan masyarakatnya. Menurut kemendiknas, karakter adalah watak, tabiat, akhlak, atau kepribadian seseorang yang terbentuk dari hasil internalisasi berbagai kebajikan (virtues) yang diyakini dan digunakan sebagai landasan untuk cara pandang, berpikir, bersikap, dan bertindak (Wibowo, 2013: 67).

Dari berbagai definisi sebagaimana telah diuraikan diatas, dapat diperoleh sebuah pengertian bahwa, karakter merupakan serangkaian sikap (attitudes), perilaku (behaviors), motivasi (motivations), dan keterampilan (skills) seseorang yang terbentuk dari hasil internalisasi berbagai kebajikan (virtues) yang diyakini dan digunakan sebagai landasan untuk cara pandang, berpikir, bersikap, dan bertindak, sehingga ia dapat hidup dan bekerjasama, baik dalam lingkup keluarga, masyarakat, bangsa, dan negara. 


\section{Nilai-nilai Karakter}

Karakter sebagaimana didefinisikan oleh Ryan dan Bohlin, yang dikutip oleh Majid (2011: 11) mengandung tiga unsur pokok, yaitu mengetahui kebaikan (knowing the good), mencintai kebaikan (loving good), dan melakukan kebaikan (doing the good). Karakter adalah kualitas atau kekuatan mental atau moral, akhlak atau budi pekerti individu yang merupakan kepribadian khusus yang menjadi pendorong dan penggerak, serta yang membedakan individu dengan individu lain. (Hidayatullah, tth:13)

Agama Islam bertujuan untuk membentuk manusia yang beriman dan bertakwa kepada Allah SWT, berakhlak mulia (berkarakter baik), mengetahui ajaran pokok Islam serta dapat mengamalkan dalam kehidupan sehari-hari dalam bermasyarakat. Tujuan Pendidikan Agama Islam ini, sejalan dengan pembentukan karakter bangsa, agar manusia mempunyai atau berkarakter unggul. Nilai-nilai karakter yang mampu diterapkan, sebagai berikut:

a. Nilai karakter yang berhubungan dengan Tuhan/keagamaan yaitu sifat religius meliputi pikiran, perkataan, perbuatan yang sesuai dengan ajaran agama Islam.

b. Nilai karakter yang berhubungan dengan diri sendiri/personality yaitu jujur, bertanggungjawab, disiplin, percaya diri, berpikir (logis, kritis, inovatif, kreatif), mandiri, ingin tahu, dan cinta ilmu.

c. Nilai karakter yang berhubungan dengan sesama manusia, lingkungan/sosial yaitu menjaga hak dan kewajiban diri sendiri dan orang lain, patuh pada aturan-aturan sosial, santun, dan demokrasi.

d. Nilai kebangsaan yaitu nasionalisme, menghargai keberagaamaan.

\section{Pembentukan Karakter dalam Perspektif Islam}

Ajaran agama Islam telah banyak mengajarkan nilai-nilai karakter yang akan diterapkan dalam kehidupan sehari-hari. Pilar-pilar karakter terdapat dalam pribadi Rasulullah Saw.

Dalam perspektif Islam karakter unggul dan mulia digambarkan dengan akhlak Nabi Muhammad SAW yang termanifestasi dalam semua perkataan, perbuatan, dan persetujuan Nabi. Akhlak unggul Nabi antara lain; benar (ashshidq), cerdas (al-fathanah), amanah (al-amanah), menyampaikan (at-tabligh), komitmen yang sempurna (al-iltizam), berakhlaq mulia ('ala khuluqin 'azhiim), dan teladan yang baik (uswatun hasanah).

Karakter identik dengan akhlak, dalam Islam karakter atau akhlak merupakan hasil dari proses penerapan ibadah dan muamalah berlandaskan dengan aqidah yang kuat. Baik dan buruk karakter bangsa sangat tergantung pada tata nilai yang menjadi pijakan. 
Al-Ghozali sebagaimana yang dikutip Wahyuddin menjelaskan, bahwa untuk mencapai akhlak yang baik ada tiga cara:

a. Akhlak merupakan anugerah dari rahmat Allah, memiliki akhlak baik secara alamiah (bi al-thabi'ah wa al-fitrah). Sesuatu yang diberikan Allah kepada seseorang sejak ia dilahirkan.

b. Mujahadah, selalu berusaha keras untuk merubah diri menjadi baik dan tetap dalam kebaikan, serta menahan diri dari sikap putus asa.

c. Riyadhoh, ialah melatih diri secara spiritual untuk senantiasa dzikir (ingat) kepada Allah dengan dawam al-dzikr.

Dengan demikian, untuk mencapai akhlak yang mulia hendaklah selalu belajar dan berusaha dalam meningkatkan kualitas diri, mempelajari akhlak yang baik dan melatih diri dalam menerapkannya. Berkumpul bersama majlis ilmu agar senantiasa membangkitkan energy dalam diri agar terus belajar dan pembiasaan.

\section{Metodologi Penelitian}

Penelitian ini menggunakan pendekatan kualitatif. Pengumpulan data dilakukan dengan teknik wawancara mendalam, pengamatan berpartisipasi, dan dokumentasi. Teknik analisa data meliputi reduksi data, penyajian data, dan penarikan kesimpulan. Pengecekan keabsahan temuan dilakukan dengan cara perpanjangan pengamatan, meningkatkan ketekunan, triangulasi, analisis kasus negatif, menggunakan bahan referensi, dan mengadakan member check. Informan penelitian adalah kepala sekolah, wakil kepala sekolah bagian kurikulum, wakil kepala sekolah bidang kesiswaan, guru kelas, siswa dan orang tua/wali.

\section{Hasil dan Diskusi}

1. Karakteristik Pembentukan Karakter Keagamaan/Religiusitas di SMP Islam Terpadu Izzuddin Palembang

SMP Islam Terpadu Izzuddin Palembang merupakan salah satu lembaga pendidikan formal yang bernaung di bawah Yayasan Ma'had Izzuddin. Secara kultur, iklim yang terbangun di sekolah ini adalah kultur pesantren yang menjunjung tinggi nilai-nilai moral atau akhlak.

Nilai-nilai karakter tersebut dijabarkan secara detail sebagai berikut:

a. Nilai karakter dalam hubungannya dengan Tuhan. religius, yang meliputi butir-butir yakni bersuci dan menjaga kesucian dengan benar, berdo'a setelah wudhu, menjalankan salat lima waktu dengan berjama'ah, salat dhuha, salat sunnah ba'diyah dan qabliyah dengan tertib dan khusu', membaca al-qur'an penuh kesadaran, membaca do'a sebelum dan sesudah aktifitas.

2. Karakteristik Pembentukan Karakter Personaliti/diri sendiri di SMP Islam Terpadu Izzuddin Palembang. 
a. Jujur, yang meliputi butir-butir jujur dalam perkataan dan perbuatan kepada siapapun.

b. Bertanggung jawab, yang meliputi kesadaran menanggung atas resiko atau akibat dari perbuatanya, dan kesadaran menjalankan apa yang telah dipercayakan kepadanya.

c. Bergaya hidup sehat, meliputi membuang sampah pada tempatnya, budaya lingkungan sekolah hijau dan bersih.

d. Disiplin yang meliputi disiplin waktu datang sekolah tepat waktu, disiplin waktu salat dhuha dan zuhur berjama'ah, disiplin ngaji dan membaca alQur'an.

e. Kerja keras yang meliputi rajin belajar, antusiasme dalam mengikuti pelajaran, kesadaran pantang menyerah dan tidak mengeluh.

f. Percaya diri yang meliputi percaya diri dalam menampilkan karya sendiri, percaya diri dalam presentasi di depan kelas, percaya diri dalam bergaul dengan dunia luar.

g. Berpikir logis, kritis, kreatif, dan inovatif antusiasme dan peran aktif dalam pembelajaran, diskusi kelas dan berkarya sebagai hasil dari proses pembelajaran.

h. Mandiri yang meliputi kemandirian dalam mengerjakan tugas pribadi, memenuhi kebutuhan dan keperluan pembelajaran, dalam berfikir dan berkarya.

i. Cinta ilmu yang meliputi semangat belajar, budaya gemar membaca, budaya berkunjung ke perpustakan buku maupun digital untuk mencari informasi dan wawasan baru.

3. Karakteristik Pembentukan Karakter Sosial/sesama dan lingkungan di SMP Islam Terpadu Izzuddin Palembang

a. Ta'dzim dan hormat kepada guru, dan semua staff

b. Santun dalam berkata / berkomunikasi dan bertindak dengan teman sebaya, guru atau orang lain.

c. Sadar akan hak dan kewajiban diri dan orang lain.

d. Menghargai karya dan prestasi orang lain dalam bentuk ruang apresiasi berupa mading.

e. Peduli sosial dalam bentuk amal, bakti sosial, santunan sosial.

f. Jum'at sejahtera dalam bentuk memberikan makanan kepada teman-teman sekelasnya

g. Peduli Lingkungan dalam bentuk menjaga kebersihan dan kehijauan lingkungan rumah dan sekolah.

4. Bagaimana Karakteristik Pembentukan Karakter Nasionalis/Kebangsaan di SMP Islam Terpadu Izzuddin Palembang 
a. Nasionalis dengan khidmah dalam mengadakan upacara dan peringatan hari-hari besar nasional.

b. Patuh pada aturan-aturan sekolah dan kesepakatan yang dibuat di kelas.

c. Demokratis dalam memilih dan dipilih dalam suksesi OSIS atau kepengurusan kesiswaan yang lain.

Apabila dikomparasikan dengan konsep karakter dasar yang dikembangkan oleh Ratna Megawangi melalui lembaganya, Indonesian Heritage Foundation $(I H F)$, yang menyebutkan ada delapan kelompok karakter, yaitu: (1) cinta kepada Allah dan semesta beserta isinya, (2) tanggung jawab, disiplin, dan mandiri, (3) jujur, (4) hormat dan santun, (5) kasih sayang, peduli dan kerja sama, (6) percaya diri, kreatif, kerja keras, dan pantang menyerah, (7) keadilan dan kepemimpinan, (8) baik dan rendah hati, dan (9) toleransi, cinta damai dan persatuan (Arismantoro, 2008: 29). Maka ada sedikit kesamaan yang substantif, meskipun perbedaan yang tidak ditemukan pada masing-masing keduanya, dimana ada jenis karakter yang nampak pada SMP Islam Terpadu Izzuddin Palembang tidak muncul pada karakter yang ada pada Indonesian Heritage Foundation $(I H F)$, dan begitu pula sebaliknya. Begitu juga bila dikomparasikan dengan konsep karakter dasar yang dirilis oleh Living Values: An Education Program (LVEP) yang didukung oleh UNESCO dan disponsori oleh Spanish Committee dari UNICEF, yang menyebutkan ada dua belas, yaitu: kedamaian, penghargaan, cinta, tanggung jawab, kebahagiaan, kerja sama, kejujuran, kerendahan hati, toleransi, kesederhanaan, kebebasan, dan persatuan (Tilman, 2004: 20). Maka ditemukan persamaan dan perbedaannya, dimana dalam konsep SMP Islam Terpadu Izzuddin Palembang lebih luas maknanya bila dibanding dengan konsep dari Values: An Education Program (LVEP).

Dalam konteks pendidikan Islam, pengembangan karakter dasar atau akhlakul karimah hendaklah dikembangkan kepada tiga dimensi yaitu dimensi keTuhanan (ilahiyah), dimensi kemanusiaan universal (insaniyah), dan dimensi kemanusiaan individual (bashariyah). Karakter yang tergolong dimensi keTuhanan meliputi: cinta Allah dan Rasul dan cinta kepada Allah dan semesta beserta isinya. Karakter yang tergolong dimensi kemanusiaan universal, meliputi: cinta orang tua/guru, cinta sesama, cinta bangsa dan negara, hormat dan santun, kasih sayang, peduli dan kerja sama, cinta damai dan persatuan, kerja sama dan toleransi. Sedangkan karakter yang tergolong dimensi kemanusiaan individual, meliputi: cinta agama sendiri, cinta ilmu pengetahuan dan teknologi, tanggung jawab, disiplin dan mandiri, baik dan rendah hati, dan kesederhanaan.

Apabila dikaji lebih tajam menurut konteks pendidikan Islam, karakter dasar yang dikembangkan oleh SMP Islam Terpadu Izzuddin Palembang merupakan konsep yang lebih lengkap dan islami karna rumusannya telah mencakup pada ketiga dimensi, yaitu dimensi ke Tuhanan (ilahiyah), 
kemanusiaan yang universal (insaniyah), dan kemanusiaan yang bersifat individul (bashariyyah).

\section{Prinsip-Prinsip Pendidikan Karakter}

Ada lima prinsip yang dijadikan landasan agar pendidikan karakter di SMP Islam Terpadu Izzuddin Palembang berjalan dengan efektif dan efisien, yaitu; (1) adanya keteladanan yang baik dari orang sekitar, (2) pembiasaan-pembiasaan yang tidak hanya sekedar mengetahui kebajikan (knowing the good) tetapi juga merasakan (feeling the good), mencintai (loving the good), menginginkan (desiring the good), dan mengerjakan kebajikan (acting the good); (3) anak memerlukan nasihat dan bimbingan; (4) kontrol dan pengawasan; dan (5) sanksi yang mendidik. Kelima prinsip yang dijadikan landasan dalam penyelenggaraan pendidikan karakter tersebut mengacu pada prinsip yang sampaikan oleh tokoh pendidikan Islam, Abdullah Nasih Ulwan, yaitu: metode keteladanan, pembiasaan, nasihat, memberikan perhatian, dan hukuman yang mendidik (Ulwan, 1981: 2). Dengan demikian prinsip-pninsip pendidikan karakter di SMP Islam Terpadu Izzuddin Palembang sebenarnya bersumber dari nilai-nilai pendidikan Islam yang telah dicontohkan oleh Rasulullah. Dalam menjalankan risalahnya, Rasulullah diutus untuk menyempurnakan akhlak (karakter) yang mulia, beliau menggunakan prinsip keteladanan, pembiasaan-pembiasaan, nasihat yang bijak, dan sanksi (pukulan) yang mendidik. Prinsip-prinsip di atas merupakan prinsip yang masih bersifat subtantif, yang membutuhkan langkahlangkah oprasional dalam implementasinya agar dapat bejalan lebih optimal. Thomas Lickona menawarkan sebelas prinsip pendidikan karakter yang disebut dengan "eleven prinsiples of effective character education" sebagai langkah operasional, yaitu: (1) mempromosikan nilai-nilai etika sebagai karakter dasar yang baik; (2) karakter dipahami secara komprehensif yang mencakup pemikiran, perasaan dan perilaku; (3) diperlukan proaktif dan pendekatan komprehensif; (4) sekolah harus menjadi masyarakat yang peduli; (5) kesempatan untuk melakukan tindakan moral; (6) memnyusun kurikulum akademis yang menghormati semua pelajar; (7) mengembangkan motivasi intrinsik siswa; (8) staf sekolah harus menjadi kumunitas moral yang bertanggung jawab untuk pendidikan karakter; (9) memerlukan kepemimpinan yang bermoral; (10) merekrut orang tua dan anggota masyarakat sebagai mitra penuh dalam upaya pembangunan karakter; dan (11) dilakukan evaluasi pendidikan karakter yang komprehensif. Dengan mengkombinasikan prinsp-prinsip islami yang subtantif dan dilengkapi dengan prinsip yang bersifat operasional dari pakar pendidikan karakter, maka penyelenggaraan pendidikan karakter di sekolah akan semakin efektif dan efisien dalam mencapai visi yang telah ditetapkan bersama-sama. 


\section{Pembentukan Karakter}

Metode pendidikan karakter yang diterapkan di SMP Islam Terpadu Izzuddin Palembang didasarkan pada lima pilar pendidikan karakter yakni knowing the good (mengetahui kebajikan), feeling the good (merasakan kebajikan), loving the good (mencintai kebajikan), desiring the good (menginginkan kebajikan) dan acting the good (mengerjakan kebajikan). Metode yang diterapkan di atas senada dengan metode yang dikembangkan oleh Thomas Lickona, yang didasarkan pada tiga komponen pendidikan karakter yang baik (components of good character). yang meliputi moral knowing atau pengetahuan tentang moral, moral feeling atau perasaan tentang moral, dan moral action atau perbuatan bermoral (Elmubarok, 2009: 110).

Berdasarkan pada hal di atas, untuk mengajarkan anak berbuat kebaikan, metode yang pertama kali harus dilakukan adalah memberikan pengetahuan secara kognitif tentang karkater yang baik kepada anak. Setelah anak mengetahui kebaikan, maka anak disentuh perasaannya untuk berbuat kebaikan agar tumbuh rasa cintanya kepada kebaikan, sehingga tumbuh keinginannya untuk melakukan kebaikan dengan kesadarannya sendiri, tanpa ada unsur keterpaksaan akibat ada tekanan dari luar.

Metode yang diterapkan dalam menumbuhkan kesadaran untuk melakukan kebaikan belum sepenuhnya membuat anak berperilaku baik. Banyak diantara anak-anak yang telah mengatahui kebaikan namun belum atau enggan melakukan kebaikan tersebut. Oleh karena itu kesadaran anak untuk berbuat kebaikan harus ditumbuhkan dengan pendekatan peningkatan keimanan atau kepercayaan yang mendasar bagi anak. Dengan lahirnya keimanan yang kuat akan mendorong anak berbuat kebaikan dengan fanatisme yang tinggi. Unsur keimanan merupakan hal yang eksistensial yang tidak boleh lepas dari pribadi anak, karena unsur keimanan ini akan melahirkan kesadaran robbaniyyah yang memberikan motivasi yang kuat untuk selalu berbuat baik (amal saleh). Dengan modal kesadaran robbaniyyah inilah, anak-anak akan berusaha memahami, merasakan, mencintai, dan berkeinginan melakukan suatu kebaikan secara konsisten.

Berdasarkan uraian di atas, tentang proses penyelenggaraan pendidikan karakter di sekolah yang dimulai dari perumusan visi dan misi, perumusan karakter dasar, latar belakang yang jelas, pemilihan prinsip dan metode yang tepat, dapat dikemukakan proposisi sebagai berikut: Apabila penyelenggaraan pendidikan karakter di sekolah didasarkan pada visi dan misi yang jelas, latar belakang yang mendasar, rumusan karakter dasar yang detail, prinsip-prinsip yang kuat dan metode-metode yang tepat, maka akan berjalan secara efektif dan efisien. 


\section{Pola Pembentukan Karakter di SMP Islam Terpadu Izzuddin Palembang}

Berdasarkan pada temuan penelitian yang telah diuraikan pada sub bab di atas, bahwa pola implementasi pendidikan karakter di SMP Islam Terpadu Izzuddin Palembang menitikberatkan pada tiga pilar besar, yaitu: Pengembangan program dan kebijakan sekolah, program pembelajaran, Kemitraan dengan wali siswa / orang tua. Dari pilar-pilar tersebut dapat disimpulkan bahwa implementasi pembentukan karakter dalam pendekatan penyelenggaraannya melibatkan seluruh anggota masyarakat sekolah, yaitu kepala sekolah, guru dan staff, siswa dan orang tua/wali. Apabila dianalisis secara tajam, pelibatan semua komponen, seperti kepala sekolah, guru, dan orang tua dalam pendidikan karakter anak merupakan keniscayaan yang tidak bisa diabaikan begitu saja, mengingat harus ada kesinambungan yang sinergis dalam pembentukan karakter anak antara di sekolah dan dan di rumah. Pembiasaan prilaku anak di sekolah harus dilanjutkan di rumah dengan bimbingan dan pengawasan orang tua. Tidak akan menjadi karakter yang baik, apabila karakter yang terjadi di sekolah kalau tidak dibiasakan di rumah, dan begitu sebaliknya. Hal inilah yang menjadikan pentingnya pelibatan orang tua demi kesinambungan pendidikan karakter di sekolah dengan karakter yang terjadi di rumah (dalam keluarga) dan bahkan luar rumah (di tengah-tengah masyarakat).

Keberhasilan pengembangan pendidikan karakter dengan pendekatan pengembangan sekolah secara menyeluruh ditentukan pada tiga komponen utama yang saling terintegrasi yaitu pengembangan program dan kebijakan sekolah oleh kepala sekolah, pengembangan program pembelajaran oleh guru, dan dan pengembangan kemitraan dengan orang tua. Dengan demikian, pendidikan karakter rnerupakan tangung jawab barbagai komponen pendidikan di sekolah (kepala sekolah dan guru/staf) dan orang tua. Dalam konteks pendidikan karakter, pembentukan karakter anak berhasil dengan maksimal bila dilakukan secara komprehensif dan integratif antara semua komponen pendidikan di sekolah dan peran serta orang tua. Pembentukan karakter anak yang dilakukan dengan parsial dan tidak adanya kesamaan persepsi, pandangan dan perlakuan dari semua komponen pendidikan di sekolah dan peran serta orang tua akan mengalami kegagalan. Berkaitan dengan hal di atas, Doni Koesoema mengandaikan adanya pendekatan yang integral diantara empat agen utama pendidikan, yaitu keluarga, lembaga pendidikan, masyarakat (termasuk di dalamnya institusi keagamaan), dan negara (Koesoema, 2010: 182). Keempat pelaku utama pendidikan ini seharusnya memiliki perhatian yang sama bagaimana membentuk karakter anak-anak sehingga menjadi pemuda yang unggul. Tampaknya konsep pendekatan terintegrasi diantara empat agen utama pendidikan dalam penyelenggaraan pendidikin karakter yang disampaikan oleh Doni Koesoema bersifat memperkuat dan menyempurnakan apa yang telah dikembangkan oleh SMP Islam Terpadu 
Izzuddin Palembang, yaitu pola pengembangan dengan pendekatan integratif. Peran dan tanggung jawab pimpinan, guru, dan orang tua dalam pembentukan karakter. Implementasi pendidikan karakter yang menitik beratkan pada pengembangan program dan kebijakan sekolah, program pembelajaran, kemitraan dengan wali siswa/orang tua, menuntut peran serta dan tanggung jawab semua komponen, yaitu kepala sekolah dan guru/karyawan serta orang tua di rumah. Keberhaslian pendidikan karakter dengan pendekatan yang integratif tersebut sangat ditentukan oleh seberapa besar peran serta dan tanggung jawab semua komponen pendidikan di sekolah dan di rumah.

\section{Kesimpulan}

Bertitik tolak pada hasil diskusi temuan penelitian yang dipaparkan pada bab sebelumnya, maka dapat disimpulkan, bahwa nilai-nilai karakter yang ditanamkan dan dikembangkan di SMP Islam Terpadu Izzuddin Palembang adalah:

1. Karakteristik pembentukan karakter keagamaan/religiusitas yang meliputi butir-butir yakni bersuci dan menjaga kesucian dengan benar, berdo'a setelah wudu', menjalankan solat lima waktu dengan berjama'ah, solat dhuha, solat sunnah ba'diyah dan qobliyah dengan tertib dan khusu', membaca Al-Qur'an penuh kesadaran, membaca do'a sebelum dan sesudah aktifitas.

2. Karakteristik pembentukan karakter personality yang meliputi butir-butir yakni jujur, bertanggung jawab, bergaya hidup sehat, disiplin, kerja keras, percaya diri, BERPIKIR logis, mandiri, dan cinta ilmu.

3. Karakteristik pembentukan karakter sosial yang meliputi ta'dzim dan hormat kepada guru, dan semua staff, santun dalam berkata / berkomunikasi dan bertindak dengan teman sebaya, guru atau orang lain, sadar akan hak dan kewajiban diri dan orang lain, menghargai karya dan prestasi orang lain, peduli sosial, dan peduli lingkungan.

4. Karakteristik pembentukan karakter nasionalis/kebangsaan yang meliputi: patuh pada aturan-aturan, dan demokratis.

Pola pembentukan karakter siswa di SMP Islam Terpadu Izzuddin Palembang bertumpu pada tiga pilar/komponen, yaitu pengembangan program dan kebijakan sekolah.yang meliputi; pimpinan sekolah sebagai model, dan pembinaan dan pemantauan SDM dan fisik, program pembelajaran, yang meliputi; pengembangan guru sebagai model karakter, pembelajaran yang efektif, dan penciptaan kelas yang kondusif, dan kemitraan dengan wali siswa dalam rangka upaya mensinergikan pembiasaan siswa, melalui: pemantauan karakter siswa di rumah atau di asrama, keteladanan orang tua/wali bagi anak di rumah, dan penciptaan lingkungan keluarga yang edukatif. 


\section{DAFTAR PUSTAKA}

Adisusilo, S. (2014). Pembelajaran Nilai Karakter. Jakarta: PT. RajaGrafindo Persada.

Arismantoro. (2008). Character Building. Yogyakarta: Tirta Wacana.

Koesoema, D. (2010). Pendidikan Karakter: Strategi Mendidik Anak di Zaman Global,. Jakarta: Grasindo.

Lickona, T. (2013). Educating For Character (Mendidik untuk Membentuk Karakter: Bagaimana Sekolah dapat Memberikan Pendidikan tentang Sikap Hormat \& Tanggung jawab), alih bahasa Juma Abdu Wamaungo. Jakarta: Bumi Aksara.

Majid, A \& Dian, A. (2012). Pendidikan Karakter Persepektif Islam. Bandung. PT. Remaja Rosdakarya.

Muslich, M. (2013). Pendidikan Karakter: Menjawab Tantangan Krisis Multidimensional. Jakarta: PT. Bumi Aksara.

Naim, N. (2012). Character Building (Optimalisasi Peran Pendidikan dalam Pengembangan Ilmu \& Pembentukan Karakter Bangsa. Yogyakarta: ArRuzz Media.

Samani, M \& Hariyanto. (2011). Konsep dan Model Pendidikan Karakter. Bandung: PT Remaja Rosdakarya.

Shihab, M. Q. (2002). Tafsir Al-Misbah (Pesan, Kesan dan Keserasian AlQur'an). Jakarta: Lentera Hati.

Tilman, D. (2004) Living Values, Living Values Activities For Children Ages 814, Pendidikan Nilai Untuk Anak Usia 8-14 Tahun. Jakarta: Gramedia Widiasmara Indonesia.

Wibowo, A. (2013). Pendidikan Karakter Anak Usia Dini. Yogyakarta: Pustaka Pelajar.

Zuchdi, D. (2008). Humanisasi Pendidikan. Jakarta: PT. Bumi Aksara. 
